\section{Seroprevalence and Risk Factors for Hepatitis A Among Montreal Street Youth}

\author{
Élise Roy, MD, MSc ${ }^{1}$ \\ Nancy Haley, MD, FRCPC ${ }^{1-3}$ \\ Pascale Leclerc, MSc \\ Lyne Cédras, MSc \\ Lucie Bédard, MSc, MPH \\ Robert Allard, MD, MSc, FRCPC ${ }^{1,3}$
}

\section{ABSTRACT}

Objective: To estimate the prevalence of hepatitis A virus (HAV) antibodies among Montreal street youth.

Method: Anti-HAV antibody testing was performed on blood samples from a hepatitis B and C study conducted among street youth in 1995-96.

Results: Among the 427 youth aged 14 to 25 years, prevalence of HAV antibodies was $4.7 \%$ (95\% confidence interval $[\mathrm{CI}]: 2.9 \%-7.2 \%)$. A multivariate logistic regression analysis showed that birth in a country with a high anti-HAV prevalence (Adjusted odds ratio [AOR]: 200.7; 95\% Cl: 38.1-1058.4), having had sexual partner(s) with history of unspecified hepatitis (AOR: 13.8; 95\% Cl: 4.2-45.2), and insertive anal penetration (AOR: 5.1; 95\% Cl: 1.6-16.7) were independently associated with infection.

Conclusion: Based on the relatively low HAV prevalence, the high prevalence of risk factors for infection, and the substantial hepatitis $\mathrm{B}$ and $\mathrm{C}$ prevalence, vaccination against hepatitis $\mathrm{A}$ is now actively promoted among Montreal street youth.

The translation of the Abstract appears at the end of the article.

Montreal Regional Public Health Department and

1. McGill University, Montreal, QC

2. Sainte-Justine Hospital, Montreal

3. Université de Montreal, Quebec

Correspondence and reprint requests: Dr. Élise Roy, Montreal Regional Public Health Department, Infectious Diseases Unit, 1301 Sherbrooke East, Montreal, QC H2L 1M3, Tel: 514-528-2400 ext. 3604, Fax: 514-528-2452, E-mail: eroy@santepub-mtl.qc.ca

Acknowledgement: This study was supported by a grant from the Laboratory Centre for Disease Control Division of HIV/AIDS Epidemiology, and Division of Bloodborne Pathogens
I n countries with a low incidence of hepatitis A virus infection (HAV), outbreaks regularly occur among injecting drug users (IDUs) and homosexual men. ${ }^{1}$ In 1995-96, we conducted a study on the prevalence of hepatitis $\mathrm{B}$ and $\mathrm{C}$ among street youth in Montreal (hepatitis B: 9.2\%; hepatitis C: $12.6 \%)$. $^{2,3}$ Towards the end of the study, the Montreal Regional Public Health Department observed an outbreak of hepatitis A among gay men. Given the high proportion of male street youth having had sex with other men $(15.5 \%)$ and the high proportion of IDUs (45.8\%) among these youth, ${ }^{2,3}$ we decided to document the prevalence of hepatitis A among street youth. We conducted a secondary analysis, using blood samples left over from the hepatitis B and C study (youth involved had agreed on the consent form to analysis of leftover specimen).

The methods of this study have been described in detail in a previous publication. ${ }^{2}$ In brief, "street active" participants aged 14 to 25 years were recruited through the ongoing Montreal Street Youth Cohort Study. ${ }^{4}$ Youth were considered "street active" if they had either been without a place to sleep more than once or had regularly used the services of Montreal street youth agencies during the previous year. The cohort study was approved by the Human Subjects (Ethics) Committee, Department of Epidemiology and Biostatistics at McGill University.

All youth completed a 15-minute faceto-face questionnaire on socio-demographic characteristics and lifetime risk factors and gave a blood sample. Anti-HAV antibody testing using Roche Cobas Core antiHAV EIA (Roche Diagnostics Systems, Mississauga, Ontario, Canada) was conducted on samples from 427 study participants. This competitive test has a cut-off value of $140 \mathrm{mUI} / \mathrm{ml}$.

The overall prevalence of HAV antibodies was $4.7 \%(20 / 427)$ with a $95 \%$ confidence interval of $2.9 \%$ to $7.2 \%$. The prevalence did not vary significantly with sex $(8.8 \%$ for women vs $5.1 \%$ for men, $\mathrm{p}=0.543$ ), while HAV-seropositive subjects were older than seronegative ones (21.0 vs 19.4 years, $\mathrm{p}=0.007$ ). Among other relevant results, we found that HAV prevalence was not associated with oro-genital intercourse or with injection drug use. The lifetime variables presenting the strongest association with HAV prevalence in uni- 
variate analyses were: birth in a country with a high anti-HAV prevalence $5(70.0 \%$ vs $3.1 \%, \mathrm{p}<0.001)$; sexual activities with a person with a history of unspecified hepatitis $(18.9 \%$ vs $3.4 \%, \mathrm{p}=0.001)$, with a female prostitute $(8.8 \%$ vs $3.2 \%$, $\mathrm{p}=0.016)$, or with an HIV-infected person ( $17.4 \%$ vs $4.1 \%, \mathrm{p}=0.020)$; having lived with someone (other than a sexual partner) infected with an unspecified hepatitis (13.2\% vs $3.1 \%, \mathrm{p}=0.002)$; and insertive anal penetration $(11.1 \%$ vs $3.6 \%$, $\mathrm{p}=0.018$ ).

Table I presents the three factors independently associated with HAV infection in a multivariate logistic regression analysis.

Our data indicated frequent co-infections. Among the 20 cases with anti-HAV antibodies, four tested positive for hepatitis $\mathrm{A}$ and $\mathrm{B}$ antibodies, two for hepatitis $\mathrm{A}$ and $\mathrm{C}$ antibodies, and four for all three. The literature suggests that patients with chronic hepatitis B have a high case fatality rate during HAV superinfection; as for coinfection with HAV and hepatitis $\mathrm{C}$ virus, the clinical implications are more controversial. ${ }^{6}$ To date, one study ${ }^{7}$ has reported a higher fatality rate among patients with HAV infection superimposed on chronic hepatitis $\mathrm{C}$, but these results have not been reproduced.

Our study showed that hepatitis A seroprevalence was low among street youth, except, as expected, among youth born in HAV-endemic countries. ${ }^{5}$ These results suggest that neither the outbreak in the gay community nor the use of injection drugs played an important role in the epidemiology of hepatitis A among street youth in Montreal at the time of the study. However, in light of the observed high proportion (21.4\%) of male subjects reporting insertive anal penetration, the association of this activity with infection suggests a potential for increased HAV incidence. The finding that oro-genital sexual contact was not a significant factor for HAV prevalence is consistent with that of other studies. ${ }^{8}$

Some limitations must be considered when interpreting the results. First, the data were collected in 1995-96. However, we are not aware of any recent epidemiological changes in hepatitis A transmission that would influence the validity of the data. Another potential limitation is the
TABLE I

\section{Factors Associated with HAV Infection in}

Multivariate Logistic Regression Analysis $(n=420) *$

\begin{tabular}{lcccc} 
Factors & $\begin{array}{c}\text { HAV+/ } \\
\text { Total }\end{array}$ & $\begin{array}{c}\text { Crude } \\
\text { Odds } \\
\text { Ratios }\end{array}$ & $\begin{array}{c}\text { Adjusted } \\
\text { Odds } \\
\text { Ratios } \dagger\end{array}$ & $\begin{array}{c}\mathbf{9 5 \%} \\
\text { Confidence } \\
\text { Interval }\end{array}$ \\
$\begin{array}{l}\text { Birth in a country with } \\
\text { high anti-HAV prevalence } \\
\text { Yes }\end{array}$ & $7 / 10$ & 71.3 & 200.7 & $38.1-1058.4$ \\
$\quad$ No & $13 / 410$ & & & \\
$\begin{array}{l}\text { Sexual partner(s) with history of } \\
\text { unspecified hepatitis } \\
\text { Yes }\end{array}$ & $7 / 37$ & 6.6 & 13.8 & $4.2-45.2$ \\
$\quad$ No & $13 / 383$ & 3.3 & & \\
$\begin{array}{l}\text { Insertive anal penetration } \ddagger \\
\quad \text { Yes }\end{array}$ & $7 / 63$ & & & $1.6-16.7$ \\
$\quad$ No & $13 / 357$ & & & \\
\hline
\end{tabular}

* 7 subjects excluded due to missing data.

$\dagger$ Adjusted for the three variables in the model.

$\neq$ The women are classified in the "no" category. generalizability of our results. However, we recruited subjects in all major organizations offering services to street youth and a recent survey of the homeless population has shown that most homeless in Montreal (over 90\%) attend community organizations offering services to homeless. ${ }^{9}$ We are thus confident that our results are generalizable to the larger Montreal street youth population.

In conclusion, the relatively low prevalence of HAV combined with the high prevalence of risk factors for infection and the substantial prevalence of hepatitis B and $\mathrm{C}$ are indications for vaccination against hepatitis A among Montreal street youth. Based on these results, vaccination of this population is now actively promoted by the Montreal Regional Public Health Department.

\section{REFERENCES}

1. Iwarson S. New target groups for vaccination against hepatitis A: Homosexual men, injecting drug users and patients with chronic hepatitis. Scand J Infect Dis 1998;30:316-18.
2. Roy É, Haley N, Lemire N, et al. Hepatitis B virus infection among street youths in Montreal. Can Med Assoc J 1999;161:689-93.

3. Roy É, Haley N, Leclerc P, et al. Hepatitis C infection among street youth. CMAJ 2001;165:557-60.

4. Roy É, Boivin JF, Haley N, Lemire N. Mortality among street youth. Lancet 1998;352:32.

5. Centers for Disease Control and Prevention. Health Information for International Travel 1999-2000, DHHS, Atlanta, GA, 1999;94.

6. Lefilliatre P, Villeneuve J-P. Fulminant hepatitis A in patients with chronic liver disease. Can J Public Health 2000;91:168-70.

7. Vento S, Garofano $T$, Renzini $C$, et al. Fulminant hepatitis associated with hepatitis A virus superinfection in patients with chronic hepatitis C. N Engl J Med 1998;338:286-90.

8. Edwards S, Carne C. Oral sex and the transmission of viral STIs. Sex Transm Infect 1998;74:610.

9. Fournier L, Chevalier S, Ostoj M, Caulet M, Courtemanche R, Plante N. Dénombrement de la clientèle itinérante dans les centres d'hébergement, les soupes populaires et les centres de jour des villes de Montréal et Québec 1996-97, 2-Montréal: Premiers résultats. [Census of the homeless population in shelters, soup kitchens and day drop-in centres in the cities of Montreal and Quebec, 1997-1997. 2-Montreal: First results.] Montréal, Canada: Santé-Québec, 1998.

Received: May 31, 2001

Accepted: November 15, 2001

\section{RÉSUMÉ}

Objectif : Estimer la prévalence des anticorps contre le virus de l'hépatite A (VHA) chez les jeunes de la rue de Montréal.

Méthode : Dépistage des anticorps anti-VHA sur les échantillons de sang d'une étude sur les hépatites B et C menée chez les jeunes de la rue en 1995-1996.

Résultats : Parmi les 427 jeunes âgés de 14 à 25 ans, la prévalence des anticorps anti-VHA était de $4,7 \%$ (intervalle de confiance [IC] à $95 \%: 2,9-7,2 \%$ ). D'après une analyse de régression logistique multivariée, la naissance dans un pays à prévalence élevée d'anticorps anti-VHA (Ratio de cotes ajusté [RCA] : 200,7; IC $95 \%: 38,1-1058,4)$, avoir eu un partenaire sexuel avec une histoire d'hépatite non précisée (RCA: 13,8 ; IC $95 \%: 4,2-45,2$ ) et les pénétrations anales actives (RCA: $5,1$; IC $95 \%: 1,6-16,7)$ étaient associés de façon indépendante avec l'infection.

Conclusion : La prévalence relativement faible du VHA, la prévalence élevée des facteurs de risque pour l'infection et la prévalence substantielle des hépatites $B$ et $C$ ont amené une promotion active de la vaccination contre I'hépatite A dans cette population. 